\title{
Social media-based visual humour use in tourism marketing: a semiotic perspective
}

\author{
Jing Ge \\ University of California, Berkeley, USA \\ jingge@berkeley.edu
}

\begin{abstract}
Tourism firms using visual social media marketing are struggling with its implementation, specifically in formulating engagement-based visual message strategies. Yet, creating such appealing posts can lead to positive brand and financial outcomes. Humour has been identified as a potent tool for social media communication, given its capability to develop social interactions. Yet, how humour works on social media is not well understood - specifically its visual form. Treating humour as a symbolic resource, this study adopted a compound content analysis-semiotic analysis to identify visual content and its symbolic meaning embedded in destination marketing organization (DMO)'s social media posts. 200 Sina Weibo posts containing humour images initiated by 5 Chinese provincial DMOs were collected. The results show 6 types of humour content and 6 types of symbolic meaning - none of which are productrelated. This study advances the tourism literature and humour theory, and offers tourism firms a holistic view of how to fully leverage social media-based visual humour to achieve consumer reach and engagement.
\end{abstract}

Keywords: humour, visual social media marketing, visual message strategies, tourism, destination marketing organizations.

\section{Introduction}

The prominent role of visual social media marketing, i.e. the practice of using digitally-mediated images (e.g., video, picture) to reach existing and potential customers more effectively (Bennett 2013), urges tourism firms to develop entertaining and relevant visual content for achieving positive marketing and financial outcomes (Gretzel 2017). It is well accepted that tourism products are essentially visual and hedonic experiences (Burns, Palmer \& Lester 2010). Visual messages that are close to the pulse of consumers are vital and cogent in constructing and perpetuating destination image, building firm-consumer relationship, generating sales, and offering firms differential advantages over competitors (Campelo, Aitken \& Gnoth 2011; Decrop 2007; Ge \& Gretzel 2019; Jenkins 2003). Although tourism marketers have acknowledged the importance of social media-based visuals and increasingly adopted them in 
an attempt to navigate the highly networked and crowded social media space, they still struggle to design optimal visual strategies that can maximize consumer engagement and related marketing outcomes (Shriner 2017).

Social media-based visual humour - an essential element for fostering a participatory culture in the digital space (Laineste \& Voolaid 2016; Marone 2016; Shifman 2012) - lends itself well to visual social media marketing. The marketing literature consistently shows that firm-initiated amusing videos, photographs and pictures are more likely to generate consumer comments, likes and reposts (e.g., Bergh, et al. 2011; Brown, Bhadury \& Pope 2010). Previous tourism studies, although few, also suggest that marketing messages containing humour images generate more consumer interactions than those containing humour words (Ge \& Gretzel 2018). Tourism, marketing and humour literatures, however, primarily focus on visual humour use in traditional media such as postcards, brochures and TV (e.g., Buijzen \& Valkenburg 2004; Catanescu \& Tom 2001; Cohen 2011; Pearce 2009). Social media-based visual humour remains unexplored.

Focusing on China, and in particular Sina Weibo (the country's most prominent microblogging platform where the use of humour for marketing is a common practice) ( $\mathrm{Ge} \&$ Gretzel 2018), this study provides a first attempt at systematically examining the use of social media-based visual humour in tourism marketing. Specifically, it adopts a semiotic approach (Peirce 1991) to identifying visual content and its symbolic meaning embedded in destination marketing organization (DMO)-published humour images. It is well recognised that Chinese DMOs are adept at using social media-based humour for consumer engagement (Ge \& Gretzel 2018). The expressive and visual affordances of social media encourage humour use as an intricate and creative way of self-expression and meaning-making, and a reflection of the sociocultural realities (Filani 2016; Laineste \& Voolaid 2016; Marone 2016). In this context, humour is well recognised as a symbol of emotional nourishment (Thomson 2010) - it allows for building a long-lived and authentic firm-consumer relationship. In light of this, this study argues that the use of social media-based visual humour goes beyond merely making consumers laugh; rather, it signifies meaningful things that resonate with them, such as different aspects of the consumers' life.

This study offers both theoretical and practical contributions. First, it broadens the humour, tourism, and marketing literatures by adding the social media context, and specifically by shedding light on visual forms of humour, and by examining humour from a semiotic perspective. Second, this research contributes to the visual social media marketing literature in tourism by introducing humour use as a more effective way to reach existing and potential customers. Third, this study helps tourism organizations enhance their marketing efforts, assists social media platforms to optimise firm-customer contact interfaces, and helps software companies develop natural language processing tools.

\section{Background}

\subsection{Visual social media marketing}

To benefit from visual social media marketing, firms need to acknowledge the consumerdominated online communication culture and develop engaging visual message strategies that move away from direct selling and hard advertising. This context is gaining relevance because 
tourism marketers are increasingly using social media-based visual messages in an attempt to initiate and maintain conversations with consumers (Ge \& Gretzel 2019; Gretzel 2017). Message strategy - a marketing approach to promoting and advertising products and brands focuses on content (i.e. what to say) and style (i.e. how to communicate things) (Leung et al. 2017), the latter being particularly important for consumer engagement. As Aristotelian scholars assert, a persuader should adopt an unconventional and pleasant language style to stimulate supportive responses from the audience (Freese 1939).

Focusing on social media, the tourism literature primarily focuses on firm-initiated visual message content while ignoring its style. For instance, in examining DMO-published photographs on Flickr, Stepchenkova and Zhan (2013) proposed fine-grained categories, such as 'nature/landscape', 'people', and 'architecture/buildings'. The findings by Ge and Gretzel (2019)'s study revealed that the use of 'landscape/nature', 'food' and 'people' by Chinese DMOs are more prevalent than 'architecture/buildings', 'leisure activities' and 'objects'. In contrast, the other line of research investigates social media messages, including visual ones, based on marketing and communication goals. For instance, Kwok and Yu (2013) examined videos and photographs published by restaurant operators on Facebook and found that entertainment and social content generate more interactions than sales- and promotion-focused content. In extending Kwok and Yu (2013)'s work, Leung et al. (2017) identified that productrelated content categories comprise 'product', 'brand', 'reward' and 'promotion'; whereas nonproduct related content include 'involvement' and 'information'. Similarly, Ge and Gretzel (2019) examined DMO-initiated visuals on Sina Weibo and found both product-related content (e.g., 'product description'; 'advertising'; 'sales') and non-product content (e.g., 'engagement'). Although these studies illuminate the role of humour involved in 'entertainment', 'involvement' and 'engagement' content, none of them sheds light on humour use in designing appealing visual message strategies.

\subsection{Humour}

Previous studies primarily examined humour, i.e. communication that is intended to be amusing to the audiences and influence their positive affect (Meyer 2000), from a philosophical, psychological, sociological, and linguistic perspective (Lynch 2002; Raskin 2008). Morreall (2008) employed three complementary theories, i.e. relief, incongruity, and superiority humour, to elaborate the philosophy of humour. Specifically, relief humour allows a speaker to release nervous energy, and reduce tension in the target audience. Public speakers, politicians and businessmen often use it to overcome communication anxiety and disclose difficult information (Lynch 2002; Meyer 2000). Incongruity humour refers to something unexpected and surprising as a result of violations of what is agreed to be normal. It allows people (e.g., advertisers, politicians) to clarify their views and make their messages memorable. In contrast, superiority humour is more likely to be a double-edged sword. It occurs as a person portrays themselves to be superior relative to the infirmity of others. On the one hand, it can be used as a social corrective through laughing at unacceptable behaviours, and to reinforce unity among group members through teasing someone else's faulty behaviour. On the other, it may not be an entertaining type of humour for people subjected to it, because it can cause the disagreeable feeling of threat to their identity (Meyer 2000). Further, the psychology of humour focuses on people's perception whether and to what extent something is funny. It also looks at their responses to humour through smiling and laughing, and therefore associates with positive 
psychology (Ruch 2008). The psychology of humour emphasizes that humour is one of the core personality strengths and virtues, and has been applied by scholars to examine humour use in health, the workplace and education (e.g., Martin 2008; Morreall 2008).

The linguistics of humour refers to the study of humorous material, specifically the conveyance of humour through humour techniques (e.g., pun, metaphor), language forms (e.g., text, picture), and meanings (Raskin 2008). Focusing on traditional forms of communication, Berger (1993) proposed the most complete typology constituting 45 types of humour. Drawing on Berger's work, Buijzen and Valkenburg (2004) developed a typology of humour in audiovisual media, comprising 41 techniques. In contrast, Raskin's (1985) semantic-script theory of humour (SSTH) differs from the taxonomic approach (Attardo 2008). It claims that the interpretation of humorous texts is based on two opposing scripts that overlap in humour. Attardo (2008) points out that SSTH can be reduced to the incongruity humour theory, because the opposition requirement is essentially comparison. Building on the SSTH, Attardo and Raskin (1991) developed a general theory of verbal humour (GTVH). It is more comprehensive than the SSTH, in that it consists of 6 knowledge resources capable of analysing long humorous texts, (e.g., novels, short stories, TV shows) (Attardo 2008). For instance, narrative strategy (NS) and language (LA) are two of the knowledge resources: the former analyses the genre of humour (e.g., riddles); the latter looks at lexical, syntactic, and phonological choices.

The sociology of humour focuses on the social functions of humour, addressing both positive and potential negative consequences of humour use. The first line of research tends to stress that humour can relieve tension in intense relationships and maintain the social order (Kuipers 2008). The notion of 'joking relationships' proposed by the anthropologist RadcliffeBrown (1940: 195) underpins this premise: "a relationship between two persons in which one is by custom permitted and, in some instances required to tease or make fun of the other". The author also claims that joking relationships are "modes of organizing a definite and stable system of social behaviour in which conjunctive and disjunctive components are maintained and combined" (200). In this context, it is well recognised that humour can assist a person to develop interactive cohesion, secure cooperation, invoke solidarity, and create affiliation (e.g., Holmes 2000; McGraw et al. 2015). Humour is also ascribed to social control or a social corrective, that is, laughing at something reveals it is outside of the normal (Billig 2005). The other line of research underlines the dark side of humour, that is, the transgressive, aggressive, and conflictive functions of humour (Kuipers 2008). Humour is often based on the transgression of societal and cultural boundaries, which can cause offense in some sort of target (e.g., groups, objects). Moreover, scholars note that people often use humour to express their negative emotions (commenting on people or things they dislike), hence facilitating hostility (Ford \& Ferguson 2004). Ethnic and political jokes can support this claim. As Meyer (2000) asserts: humour is concerned with the construction of a 'we', which implies inclusion as well as exclusion. To summarise, humour scholarship has sought to identify the causes of humour, why it exists, and why humour is funny, and paid less attention to the semiotic perspective of humour.

\subsection{Humour use in marketing}

The beneficial aspects of humour (see section 2.2) suggest that humour lends itself well to social media marketing. Previous studies have given much more focus to script and verbal humour than visual humour - this gap deserves scholarly attention due to the prevalence of social mediabased visual humour (Marone 2016; Shifman 2007). This study is a response. Given the limited 
research on the semiotics of humour (Gluscevskij 2017; Marone 2016; Tsakona 2009), this study focuses on the semiotic use of social media-based visual humour by treating it as a sign - it constitutes a signifier or an observable object and a signified meaning (Chandler 2007). For example, a photograph showing a facial expression (i.e. a signifier) may signify a person's attitudes towards his/her life situations (i.e. a signified meaning).

The significance of humour semiotics in marketing and communication is that it goes beyond drawing consumers' attention and making them laugh; rather, it creates shared symbolic meaning that allows for invoking solidarity and creating affiliation with consumers (Ritchie 2001). Yet, the marketing literature primarily focuses on proposing humour typologies (e.g., pun, ridicule, comparison) in the context of traditional advertising such as TV and print (Catanescu \& Tom 2001; Kelly \& Solomon 1975; Rieck 1997; Speck 1990). The common consensus is that humour has great potential to draw consumers' attention and encourage them to elaborate messages. These humour typologies have been adopted in conducting a comparative study across cultures (Laroche, Nepomuceno \& Richard 2014). The authors found that the successful use of humour in advertising largely relies on the symbols and stereotypes in specific contexts. Similarly, Tresidder (2014) points out that symbolic meaning is a core of marketing messages - it permits tourism marketers to create and satisfy consumers' desires and expectations by taking into account their social and cultural experiences. Applied to the social media marketing context, the semiotics of humour use can provide marketers with a route to creating and developing a consumer-endorsed online community.

\subsubsection{Humour in tourism}

While humour has great potential to enhance tourism firms' social media marketing efforts, the tourism literature primarily focuses on humour use in traditional forms of communication. The well-recognised adoption areas include product promotion, travel writing, experience staging, and host-guest relationships (Gretzel 2015). Focusing on the offline domain, Pearce and Pabel (2015) contend that humour allows for creating positive tourism through offering the connection between positive psychology and tourism. Relief, incongruity and superiority humour can underpin this claim. Specifically, humour can reduce tourists' anxiety or discomfort due to an unfamiliar environment. Amusing and light-hearted messages can motivate tourists to concentrate on and actively process information while travelling (e.g., safety messages). Further, previous studies found that tour guides with a sense of humour are able to reassure tourists who are anxious about a new and uncertain environment/experience, engage their sympathies and build rapport (Pabel \& Pearce 2016a; Pabel \& Pearce 2016b; Pearce 2009). Research on humour use in traditional media highlights its effectiveness in tourism promotional campaigns and advertising. For instance, consumers are more likely to concentrate on, disseminate and discuss humorous tourist postcards, brochures and advertising, and increase their willingness to visit certain destinations (Cohen 2011; Pearce 2009).

The rhetorical functions of humour, i.e. identification and clarification (Meyer 2000), can also explain this positive side of humour. The former suggests that humour can build support by identifying communicators with their audiences and enhancing speaker credibility; the latter addresses that communicators can use humour to formulate their ideas into appealing messages. In this context, scholars and marketers also need to consider the negative side of humour. In examining consumer engagement through humour, $\mathrm{Ge}$ (2017) found that consumers sometimes express negative sentiment to respond to firm-initiated humour, challenging the usefulness of humour in generating positive affect. Indeed, drawing on the transgressive, aggressive, and conflictive functions of humour (Kuipers 2008), one can assert that certain types of humour 
(e.g., satire, ethnic and political humour) are not appropriate in tourism. The other two rhetorical functions of humour, i.e. enforcement and differentiation (Meyer 2000), can explain this. The first notes that humour permits communicators to enforce norms by levelling criticism; the second suggests that humour is invoked to make distinctions, rather than alliances. For example, politicians use humour to contrast themselves with their opponents.

The use of social media-based humour in tourism is no longer only about advertising and promoting tourism products; rather, it needs to focus on consumer's needs and interests. The participatory culture facilitated by social media-based humour (Shifman 2012) calls for a new way in which tourism firms should communicate and promote their products and services. As Ge and Gretzel (2018) suggest, the experiential and hedonic nature of tourism products requires firms to develop entertaining and meaningful social media posts that are of relevance to different aspects of consumers' life. Previous studies, although few, shed light on this new use of humour. Ge and Gretzel (2018) found that DMOs use humour not only to promote their destination but also to convey self-expression and phatic communication to keep the conversation space active. Ge (2017) found that DMOs adopt humour to humanize the brand and fuel their marketing messages with a human voice. These studies bear out the idea that tourism marketers should not adopt humour strategies similar to those used in traditional forms of communication on social media platforms. However, the tourism literature is lacking an adequate theory related to the use of humour in the context of social media.

\subsubsection{Social media-based humour}

Social media-based humour, i.e. humour presented through the means of digitally-mediated platforms (e.g., social networking and microblogging sites) (Filani 2016), has changed its techniques, communication forms and topics in response to social, cultural and technological trends (Shifman 2007). These shifts raise challenges for theoretical and practical understandings of social media-based humour use in tourism. In addition to reclaiming existing humour, social media-afforded interactivity and multimedia have created new humour techniques, for example, humorous PowerPoint files and interactive humour (i.e. it requires users to perform an action to achieve humorous effect such as clicking or inputting text) (Shifman 2007). Moreover, digital technologies have fostered new or adapted visual forms of humour, such as photograph/picture collages, maniphotos (i.e. manipulated photographs through digital technology), and phanimations (i.e. animated GIF or photo composition created with Photoshop) (Marone 2016). Importantly, these visual forms of humour are found to be more prevalent than script/verbal humour in the digital space - they have become the core of playful and sustaining interactions on diverse social media platforms, for example Vine, Instagram, YouTube, Facebook and Sina Weibo (Ge \& Gretzel 2018; Highfield \& Leaver 2016; Marone 2016; Shifman 2007). Last but not least, online communication without geographical boundary has impacted the creation and popularity of humour topics. For instance, sex, animals and genders are global-oriented humour topics, whereas ethnicity, politics and habits are local topics (Laineste \& Voolaid 2016; Shifman 2007). In a nutshell, social media-based humour goes beyond and is much more complex and innovative than humour in traditional media.

The significance of social media-based visual humour in tourism is that it permits firms to stand out from the noisy and crowded online space, and encourages the practice of sharing (Weitz 2016), including sharing as distribution, sharing as participation and sharing as communication (Shifman 2013). Sharing as distribution - the activity of forwarding humour to 
other users - allows for reaching existing and potential customers. This line of research largely focuses on viral videos and visual parodies (Bergh, et al. 2011; Brown, Bhadury, \& Pope 2010, Burgess \& Green 2018). Research on sharing as participation - using humour to generate cooperative actions from the audience - concentrates on online political campaigns (Shifman, Coleman, \& Ward 2007), regardless of its crucial role in engaging consumers on social media, for instance, encouraging consumers to participate in online marketing events. Sharing as communication - responding through laughter (e.g., 'haha' or smiley emoji) and responding through humour (Ge 2017; Knight 2008) - suggests that humour can be used to shape amusing interactions. To summarize, the practice of sharing through humour use creates and reinforces group identity and solidarity, and shows one's capability of identifying and using humour (Laineste \& Voolaid 2016). Clearly, humour as a form of sharing provides tourism firms an opportunity to enhance their social media marketing efforts. A means of using social mediabased visual humour to stimulate the sharing practice remains overlooked in the marketing and tourism literature.

\subsubsection{Semiotics}

Semiotics - both a theory and method for interpreting meaning embedded in signs (Peirce 1991) - has an important role to play in understanding social media-based visual humour in tourism. Tourism visuals are essentially semiotic - they always stand for something else that goes beyond merely depicting travel-related people, places and things; rather, they signify various potential experiences and practices that attract and direct touristic gazes (Dann 1996; Tresidder 2014). For instance, a destination-related image can denote a particular place (e.g., mountains) while it also carries a certain symbolic value based on personal, social or/and cultural connotations (e.g., adventure, escape). Moreover, the use of visual humour for meaning-making, such as signifying one's daily life, and social and political conflicts, is a common user practice on social media (Ge 2016; Laineste \& Voolaid 2016; Marone 2016). From a theoretical perspective, semiotics identifies the content and meaning of denotative (literal) and connotative (interpretation subject to socio-cultural or personal association) sign elements in images (Moriarty 2005) and interprets them with regards to their iconic, indexical or symbolic significance (Peirce 1991). Specifically, iconic signs are highly recognizable and literal resemblances to the original such as a subway map. Moreover, indexical signs are an indicator of the existence of something, such as a signpost with a letter ' $\mathrm{P}$ ' indicating a parking area. Finally, symbolic signs represent something by social conventions, cultural norms or institutions, such as a flag for a country and a mascot for a team (Metro-Roland 2009).

Semiotics has become and continues to be both an important subject matter and a pertinent methodology applicable to many aspects of tourism (Zhang \& Sheng 2017). Yet, semiotic studies remain scarce in relation to social media-based visuals in tourism. A few studies examined the adoption of firm- and/or consumer-generated photographs for building and perpetuating a particular destination image (e.g., Hunter 2013, 2015, 2016; Lian \& Yu 2017; Pennington \& Thomsen 2010; Thomsen \& Vester 2016). For instance, Thomsen and Vester (2016) used Peirce's sign system to develop a visual semiotic-based authenticity typology including iconic, indexical and symbolic authenticity. Other scholars adopted a combination of content analysis and semiotic analysis (Hunter 2013, 2015, 2016; Lian \& Yu 2017; Stepchenkova \& Zhan 2013). 
For example, Stepchenkova and Zhan (2013) compared firm- and consumer- generated photographs on Flickr. While content analysis was used to identify and categorize the visual content depicted in photographs (e.g., landscape/nature, local food), visual semiotics was adopted to analyse the iconic/symbolic dimension of these visuals (e.g., way of life, adventure). Lo and McKercher (2015) looked at how online visuals are used for impression management by employing a combination of interviews and semiotic analysis. A common characteristic of all identified tourism-related visual semiotics studies is that they largely ignore the uniqueness of visuals on particular online platforms and the visual practices in which they are embedded. As such, existing tourism literature that focuses on visual semiotics in the context of online tourism provides little guidance for studying emergent social media-based visual humour.

In summary, visual social media marketing is rewarding but challenging - it requires tourism marketers to develop entertaining and relevant visual content to reach and resonate with consumers who play a dominant role in online spaces. Visual humour has been identified as a potent tool for social media marketing communication, given its capability of developing the practice of sharing. However, existing tourism literature primarily focuses on humour usages in traditional media. Furthermore, it is well recognised that the communicative, expressive, and semiotic affordances of social media platforms encourage humour use as new ways of expression, meaning-making, and a reflection of the sociocultural realities. Yet, existing humour literature in the marketing domain exclusively focuses on humour techniques and modalities and ignores their semiotic significance. In responding to these literature gaps, this study aims to examine and answer the following research questions:

RQ1: What types of content does social media-based visual humour convey?

RQ2: What types of symbolic meaning are embedded in social media-based visual humour?

\section{Visual methodology}

Visual methodology aims at examining and capturing social reality through a variety of visual forms (e.g., photograph, video, painting) (Rose 2016) and allows this study to systematically examine social media-based visual humour. This methodology describes both traditional and online media as a system of signs that conveys denotative (literal) and connotative (implied) meanings (Hunter 2015). In tourism studies, the meanings of signs can be examined using interpretative approaches (e.g., discourse analysis, content analysis, semiotic analysis) individually or in combination to understand the visual representations identified in different media channels (Hunter 2015). This study adopted a compound content analysis-semiotic analysis methodology. This method was used by previous tourism research on photographs published in print media (e.g., travel brochures and guidebooks) (Jenkins 2003) and on the Internet (Hunter 2013, 2015, 2016; Lian \& Yu 2017; Stepchenkova \& Zhan 2013). Specifically, content analysis was adopted to identify types of visual representations in destination-related photographs; semiotic analysis was used to identify the symbolic meaning of these visual representations (e.g., Hunter 2015; Lian \& Yu 2017). Online-based research has also focused on verbal qualitative data using 'phenomenography' (Govers, Go, \& Kumar 2007). The full potential of visual methods in tourism research has yet to be realized (Hunter 2015). This paper is intended to contribute to this body of literature in tourism research. 


\subsection{Online visual data and sampling}

The data of this study are Sina Weibo posts that contain humour images. Because social mediabased visual humour in tourism is a new line of inquiry, this study sought information-rich samples that captured the phenomena it was interested in (Bauer \& Gaskell 2000). Hence this study sampled humorous images as used by Chinese DMOs on Sina Weibo - a 'humour hub' where publishing and forwarding humour (including visual forms) by both individuals and business users is one of the most common activities (China Daily 2015; Ge 2017). Moreover, the sampled DMOs are not only active social media users but proficient humour users who are adept at producing interesting and relevant content (involving e.g., personal life, social issues, life philosophy) (Ge \& Gretzel 2018). They can be conceptualized as lead users and thus as particularly important in informing the understanding of social media-based visual humour usages. To examine this tendency further, this study selected a sample of 5 DMOs through pretesting the frequency of posts and the frequency of humour posts published in two weeks: Shandong DMO, Sichuan DMO, Henan DMO, Jiangxi DMO and Zhejiang DMO. Next, this study selected humour images published by these DMOs from 10 September 2014 to 10 November 2014 based on visual humour techniques proposed by Berger (1993). In total, 200 DMO-initiated static and animated humour images were collected, a size considered effective for a manual coding study (Kolbe \& Burnett 1991).

\subsection{Content-semiotic analysis}

A compound content analysis-semiotic analysis includes two phases: The first phase examining elements within the images as denotative types - was conducted to identify types of visual content; the second phase - analysing secondary connotative sign elements - was carried out to identify symbolic meaning encoded in the humour content. This procedure has been employed in previous tourism research to categorize photographs (e.g., Stepchenkova \& Zhan 2013). Denotative elements in the photographs were understood as those that resemble reality, are form-specific and relatively independent of social context; connotative elements were understood as supplemental to reality and dependent on social and cultural context (Hunter 2015).

Analysing humour language on social media is a critical challenge for artificial intelligence due to its complexity (Anderson 2016). Automatic coding therefore is not feasible. A sample set comprising 50 posts was coded by the author and a Chinese graduate student with expertise in cultural communication. The Cohen's Kappa for coding the visual humour content was 0.93, indicating a solid agreement (Cohen 1960). The remainder of the images were discussed with a linguistic expert and were then coded by the author. The coding of visual content was guided by: 1) considering each image as a single unit of content; and 2) coding essential attributes within the visual based on size and location within the visual. For instance, some of the categories emerging from the data include people, sculpture and animal. To identify their symbolic meaning, this study treated these humour image attributes or sign elements as symbols and examined what they signify beyond mere appearances. For example, a picture showing a couple fighting was coded as 'people' (i.e. visual content) and was then coded as 'relationship' (i.e. symbolic meaning).

\section{Results}

The social media-based visual humour in the dataset is delivered through both static and animated images. The static images include pictures, photographs, photograph/picture collages, 
and maniphotos, while the animated images comprise only GIFs. The frequency distribution results of the visual contents and their symbolic meaning are presented first, followed by examples illustrating the prominent categories.

\subsection{Visual humour content}

There are 6 types of visual humour content depicted in the Sina Weibo data. As Table 1 shows, 'people' accounts for the largest percentage, followed by 'animals' and 'objects'. In sharp contrast, 'sculpture' and 'food' are rarely used categories. Not all of the identified categories are relevant to tourism product promotion and advertising. The DMOs in the dataset often used humour pictures, photographs and maniphotos to depict adults and children in general and celebrities (e.g., actor/actress); they also employed both maniphotos and GIFs to depict nonlocal animals such as dogs and cats. 'Tourists', 'the locals' and 'local animals' - the prominent tourism visual content (Stepchenkova \& Zhan 2013) - are absent in the data. With respects to 'objects', the sample DMOs used cartoons to assign human characters to material things (e.g., a toothbrush with a screaming face), also known as humanization. A detailed discussion that pertains to visual humour content is presented in Section 5.

Table 1. Visual humour content: descriptions and frequency distribution

\begin{tabular}{|c|c|c|c|}
\hline Category & Description & Count & Percentage \\
\hline People & $\begin{array}{l}\text { Celebrities, and adults and } \\
\text { children in general depicted in the } \\
\text { centre of the image. }\end{array}$ & 95 & $47.5 \%$ \\
\hline Animals & $\begin{array}{l}\text { Local animals and animals in } \\
\text { general in the centre of the image. }\end{array}$ & 48 & $24 \%$ \\
\hline Objects & $\begin{array}{l}\text { Material things, e.g., toothbrush, } \\
\text { umbrella. }\end{array}$ & 31 & $15.5 \%$ \\
\hline People \& Animals & $\begin{array}{l}\text { Both people and animals depicted } \\
\text { in the centre of the image. }\end{array}$ & 14 & $7 \%$ \\
\hline Sculpture & Traditional art objects. & 6 & $3 \%$ \\
\hline Food & Food in general. & 6 & $3 \%$ \\
\hline Total & & 200 & $100 \%$ \\
\hline
\end{tabular}

\subsection{Symbolic meaning of visual humour}

The data analysis shows that the different types of humour content in the Sina Weibo data signify 6 categories of symbolic meaning. As Table 2 presents, 'relationship' and 'life value' are the most prevalent, followed by 'way of life' and 'personal feelings'. The DMOs in the dataset often used humour images that depict 'people' and 'animals' to symbolically convey different 'relationships' and 'life value': the former includes friendship, romantic relationship and family relationship, the latter is largely concerned with one's personal attitude towards wealth, adversities, success and happiness (Figure 1). They sometimes also used 'people' and 'animal' to signify 'way of life' and 'personal feelings': the first refers to a person's specific habit or 
behaviour, the second is concerned with a person's emotional reaction towards certain things (e.g., upcoming holiday, a sudden loss of Internet) (Figure 2). Conversely, the sample DMOs rarely employed humour content that depict 'people' to create symbolic meaning with regards to 'identity' (i.e. the distinguishing character or personality of an individual) and 'social power' (i.e. a person's influence on others due to his/her skill, knowledge and status). For example, Shandong DMO used a picture collage that depicts people to signify different professionals and their unique characters (i.e. 'identity'). A detailed discussion that pertains to symbolic meaning of social media-based humour is presented in Section 5.

Table 2. Symbolic meaning of visual humour: descriptions and frequency distribution

\begin{tabular}{|c|c|c|c|}
\hline Category & Description & Count & Percentage \\
\hline Relationship & $\begin{array}{l}\text { The way in which two or more } \\
\text { people regard and/or behave } \\
\text { towards each other, such as } \\
\text { friends, romantic partners, and } \\
\text { family members. }\end{array}$ & 67 & $33.5 \%$ \\
\hline Life value & $\begin{array}{l}\text { The way in which people view } \\
\text { different aspects of their life, such } \\
\text { as career, marriage, wealth, } \\
\text { adversities. }\end{array}$ & 53 & $26.5 \%$ \\
\hline Way of life & $\begin{array}{l}\text { The typical pattern of behaviour of } \\
\text { a person or group. }\end{array}$ & 40 & $20 \%$ \\
\hline Personal feelings & $\begin{array}{l}\text { One's emotional reaction towards } \\
\text { certain things and social issues. }\end{array}$ & 31 & $15.5 \%$ \\
\hline Identity & $\begin{array}{l}\text { The distinguishing character or } \\
\text { personality of an individual. }\end{array}$ & 5 & $2.5 \%$ \\
\hline Social power & $\begin{array}{l}\text { One's influence on other people } \\
\text { due to his/her skill, knowledge and } \\
\text { status. }\end{array}$ & 4 & $2 \%$ \\
\hline Total & & 200 & $100 \%$ \\
\hline
\end{tabular}


你身边的那个她是不是也经常这样。

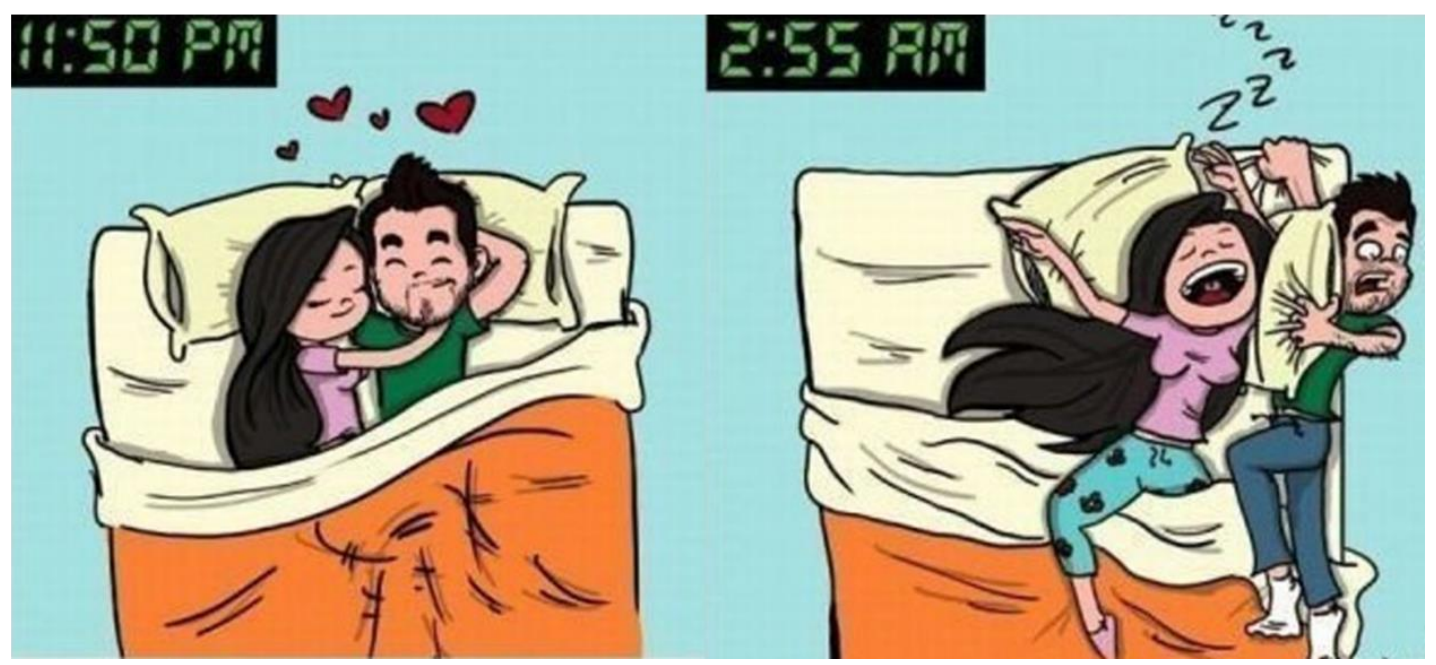

Figure 1. Picture collage that depicts 'people' and signifies 'relationship' (Source: Shandong DMO-initiated post

https://www.weibo.com/1870458911/BozeODEEL?from=page_1001061870458911_profile\&

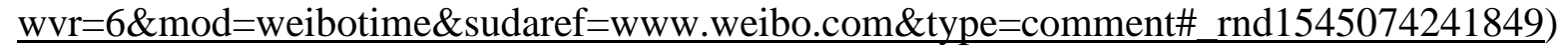

NOTE: The loose translation of the text is: "Is your partner like her."

上班族的各种感觉，招招命中啊！！-

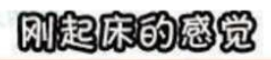
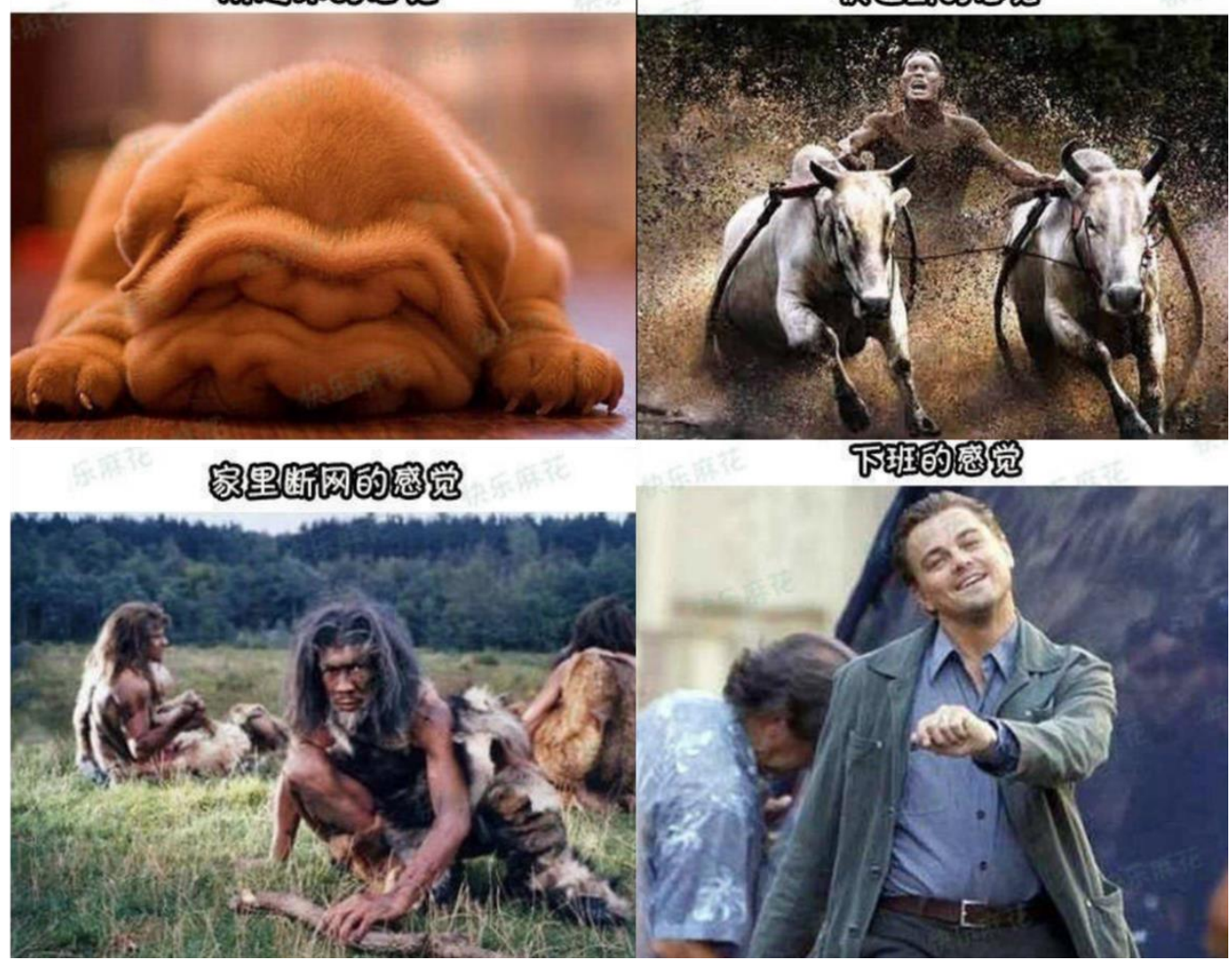
Figure 2. Photograph/picture collage that depicts 'people', 'animal' and 'people \& animal' and signifies 'personal feelings' (Source: Shandong DMO-initiated post https://www.weibo.com/1870458911/BmrfSfK9S?mod=weibotime\&type=comment _rnd1545076438660)

NOTES: The loose translation of the text is: "All kinds of feelings of office workers, and I have experienced all of them!!" The loose translation for the superimposed is: 1) "the feeling of getting up; 2) "the feeling of being late for work"; 3) "the feeling of losing the Internet at home"; and 4) "the feeling of coming home from work".

\section{Discussion and conclusion}

\subsection{Research questions revisited}

The results of the first research question - what types of content social media-based visual humour conveys - reveal the adoption of non-product-related content. 'People' and 'animal' are the most prevalent, whereas 'sculpture' and 'food' are the least used categories. The identified results extend product-focused humour content in the marketing and tourism literatures; they also support the notion that successful marketing on social media requires tourism firms to focus on consumers and their interest (Gretzel \& Yoo 2013). Moreover, the prominent categories, i.e. 'people' and 'animal', are consistent with humour content of Internet-based humour (Shifman 2007). These results also underpin Shifman's conclusion that global-oriented humour content categories such as people and animal are more popular than local-oriented ones such as ethnicity. While the humour literature suggests Internet-based memes delivered through maniphotos often focus on politicians (Shifman 2012), this study found that DMOs use either celebrities (e.g., singer, actor/actress) or people in general. This result echoes Ge (2017)'s postulation: firms should focus on the positive effect of humour and stay away from using political humour due to its potential negative effect. Indeed, because social media provide firms and consumers with a two-way conversation space, it is reasonable to assume that if firms deploy humour involving politicians and political issues, customers may co-construct such humour as personal attacks and public shaming which could backfire on a firm's visual social media marketing endeavour. Noteworthy is that although the popularity of humour video is well recognised in the humour literature, videos are missing in the Sina Weibo data. The plausible reason might be that the sample DMOs took technological and time constraints into consideration. For instance, watching humour videos requires both a stable Internet connection and enough time.

The identified humour content can be explained by the humour theories discussed in section 2.2. Compared to product-related content, the use of 'people' (especially celebrities and children) and 'animals' (especially those related to Internet memes) may allow firms to release potential tension (i.e. relief humour) in the consumer-dominated social media space. Moreover, surprise created by these content categories can also draw consumers' attention and then motivate them to process and memorise the key messages formulated therein (i.e. incongruity humour, SSTH). Interestingly, people presented in visual humour portray themselves to be superior relative to the infirmity of animals or children in a benign manner; firms sometimes also deprecate themselves (i.e. superiority humour). This allows them to invoke solidarity and create affiliation with consumers, and avoid the aggressive and conflictive functions of humour 
(i.e. the sociology of humour). The avoidance of the dark side of humour is also seen from the previous observation of the non-use of local-based humour content (e.g., politics, ethnicity).

The results of the second research question - what types of symbolic meaning are signified in social media-based visual humour- show a prevalence of 'relationship' and 'life value', and a rather rare use of 'identity' and 'social power'. Importantly, the embedded personal and social significance in such humour creates symbolic attractiveness that resonates with the audience (Crilly, Moultrie, \& Clarkson 2004) - it may encourage consumers to not only passively consume but actively respond to firm-initiated social media posts. What is perhaps surprising is that the identified symbolic meanings are entirely consumer-focused. It supports the suggestion that social media marketing calls for a symbolic branding strategy - it needs to champion new ideologies that are meaningful to customers (Holt 2016). Likewise, Chathoth, et al. (2016) suggest that tourism marketers should treat consumers as friends, focus on things that matter to them, and solve their problems.

Building on the humour literature, this study suggests that such prevalent symbolic meaning can be explained by one of the rhetorical functions of humour, that is, identification (Meyer 2000). In other words, they allow tourism marketers to identify with consumers, fit into their community, and obtain their support. Furthermore, another social function of humour (i.e. differentiation) (Meyer 2000) and Chinese culture might explain the rare use of 'identity' and 'social power'. Both of them are concerned with making distinctions (or distinguishing someone from others), rather than developing alliances. Besides, Chinese culture advocates establishing and maintaining a network of friendships; a person needs to do communal sharing to foster unity, community, undifferentiated collective identity and kindness (Hwang 2000). In light of this, one can say that unlike 'relationship' and 'life value', the use of 'identity' and 'social power' may possibly play a negative role in creating and continually developing a positive and united online community.

\subsection{Theoretical implications}

The overall results derived from this study support the assertion that visual humour use on social media acts as a creative way of socialization, self-expression, and meaning-making. In addition to traditional communication forms (i.e. pictures, photographs), firms tended to use new humour modalities (i.e. maniphotos, GIFs) (Shifman 2007) as a starting point to reach consumers. Such innovative approaches were also found in the way they present visual humour: the use of photograph/picture collages to create amusing coherent narratives and choosing popular celebrities as target. Moreover, the expression of feelings/emotions suggests that firms departed from direct promotion and hard selling; humour imbued with a human voice allows for brand humanization. The literature noted that humour can help people be more creative in problem solving (Holmes 2000). This notion is affirmed by how the sample DMOs used visual humour to convey the variety of symbolic meanings in order to resonate with consumers. For instance, characters involved in the most prominent category (i.e. relationship) include not only people (i.e. ordinary people, celebrities) but also the popular animals in online memes (e.g., fat cat, naughty dog). One can claim that these characters can encourage consumers to identify and interpret meanings embedded in humour and then interact with firms. Although this study does not focus on the identification of humour techniques, observations that occurred during data collection suggest that firms often used social media-afforded modalities to deliver a variety of humour types that belong to typologies of humour in audio-visual media (e.g., 
anthropomorphism, visual surprise) (Buijzen \& Valkenburg 2004) and in the context of traditional advertising such as TV and print (e.g., comparison, ridicule) (Catanescu \& Tom 2001; Kelly \& Solomon 1975; Rieck 1997; Speck 1990). These observations indicate that firms fully leverage the technological basis of social media in the humour context.

The identified non-product-related humour content and symbolic meaning support the argument of this study - the use of social media-based humour differs from that in traditional media. The results, moreover, extend the capability of humour in visual social media marketing in tourism: it allows for fostering a participatory culture and permits tourism marketers to effectively reach and connect with existing and potential customers. This proposition itself, however, raises a question about why social media-based visual humour is able to help firms accommodate and navigate the highly networked and crowded social media space. One way to address this question is to examine economic, social and cultural logics of participation. The economy-driven logic relates to the notion that contemporary society is based on an 'attention economy' - the most valuable resource in the information era is not information but the attention people pay to it (Lanham 2006). It particularly pertains to non-product related humour content - consumers tend to pay attention to engagement-based marketing messages more than product promotion and advertising (Leung et al. 2017). The social logic of participation would suggest that social media-based visual humour is highly compatible with the age of 'networked individualism' - people construct their unique identity and seek for like-minded communities at the same time (Wellman et al. 2003). On the one hand, responding to firm-initiated humour images can demonstrate that consumers are proficient and creative social media users; on the other, creating and endorsing shared symbolic meaning of humour may relate to a common ground and affiliation. Finally, the cultural logic of participation draws on the notion that social media-based visual humour serves as the building blocks of complex cultures that entice consumers to engage in the cultural practices surrounding them (Burgess \& Green 2018).

\subsection{Practical implications}

This research provides tourism firms with an understanding of the use of social media-based visual humour to enhance their marketing efforts. The non-adoption of product promotion and advertising elements in formulating humour posts inform marketers that engagement is the core of social media marketing. Moreover, the identified humour content and symbolic meaning offer them a conceptual map with regards to how to design and employ entertaining and relevant social media posts as stepping stones for consumer engagement. This new paradigm is especially relevant to DMOs. While getting exclusive deals is the most common motivation for consumers connecting to travel companies, information needs and opportunities for emotional connections also motivate consumers to connect with DMOs and openly show their association with DMOs to others (Gretzel \& Fesenmaier 2012). In this context, the emotion-laden symbolic meaning categories (e.g., 'relationship', 'life value', 'personal feelings') advise DMOs that humour can act as an emotional nourishment for building relational capital; meanwhile, these diverse categories offer DMOs a shared symbolic repertoire for developing a united community. Last but not least, firms should be aware of potential pitfalls of humour use, and ensure that its symbolic meaning is appropriate in the tourism marketing context. For instance, tourism marketers should stay away from using Internet memes conveying political issues and negative news, due to the potential adverse effect on fostering a harmonious firm-consumer relationship. 


\subsection{Limitations and future research}

As the first attempt of examining social media-based visual humour in tourism, this research of course has its limitations. First, the data were primarily coded by one person. While confirming the coding scheme with an additional coder and discussions with a linguistic expert added reliability, such a one-person approach is limited in terms of objectivity and providing multiple perspectives. However, this process allowed for consistency in the method (Fereday \& MuirCochrane 2006) and permitted the researcher to systematically identify visual humour content and its symbolic meaning. Further, the coding of the symbolic meaning of humour requires deep observation, and calls for the skills, insights and analytic abilities of a researcher with elaborate domain expertise (Elo \& Kyngäs 2008). Second, this research only used Sina Weibo; however, it is the most influential social media platform in terms of humour use and thus can be seen as a best practice case. Finally, to conduct in-depth analysis, this research only selected five active DMO cases, so the findings might not apply to all tourism and hospitality firms. Further applications of the proposed conceptual categories allow for testing of their stability. Despite these limitations, the findings of this research can provide a holistic view of the complex humour phenomenon on social media. Further, the methodological approach is transferable, which means the taxonomy can be applied to study other contexts.

To further extend research in this area, humour adoption by other firms, other industries and on different social media platforms could be the focus, because this would shed light on how the nature of the products and services and technological basis influence humour structure and use. Focusing on the communication perspective, the peculiarity of Chinese culture and especially its social media culture suggest that another future branch of this research could consider different cultural contexts. Finally yet importantly, future research can build on different types of social media-based visual humour content and symbolic meaning, for instance by investigating the effectiveness for each identified category.

\section{References}

Anderson, M. (2016). 'Why sarcasm is such a problem in artificial intelligence'. February 11. Stack. Retrieved March 10, 2016 from https://thestack.com/cloud/2016/02/11/whysarcasm-is-such-a-problem-in-artificial-intelligence/.

Attardo, S. (2008). 'A primer for the linguistics of humor', in Raskin, V. (ed.), The Primer of Humor Research, Berlin and New York: Mouton de Gruyter, pp. 101-155.

Attardo, S. \& Raskin, V. (1991). 'Script theory revis(it)ed: Joke similarity and joke representational model.' Humor. International Journal of Humor Research (4) 3, pp. 293347.

Bauer, M. W. \& Gaskell, G. (2000). Qualitative Researching with Text, Image and Sound. London: Sage.

Bennett, S. (2013). 'What is visual social media marketing (and how does it raise engagement)?'. March 12. Adweek. Retrieved January 5, 2016 from http://www.adweek.com/socialtimes/visual-social-marketing/479112.

Berger, A. A. (1993). An Anatomy of Humor. Piscataway: Transaction Publishers.

Bergh, V. B. G., Lee, M., Quilliam, E. T. \& Hove, T. (2011). 'The multidimensional nature and brand impact of user-generated ad parodies in social media'. International Journal of Advertising 30 (1), pp. 103-131.

Billig, M. (2005). Laughter and Ridicule: Towards a Social Critique of Humour. London: Sage. 
Brown, M. R., Bhadury, R. K. \& Pope, N. K. L. (2010). 'The impact of comedic violence on viral advertising effectiveness'. Journal of Advertising 39 (1), pp. 49-66.

Buijzen, M. \& Valkenburg, P. M. (2004). 'Developing a typology of humor in audiovisual media'. Media Psychology 6 (2), pp. 147-167.

Burgess, J. \& Green, J. (2018). YouTube: Online Video and Participatory Culture. Hoboken, NJ: John Wiley \& Sons.

Burns, P. M., Palmer, C. \& Lester, J. A. (2010). Tourism and Visual Culture. Volume 1: Theories and Concepts. Wallingford, UK: CABI.

Campelo, A., Aitken, R. \& Gnoth, J. (2011). 'Visual rhetoric and ethics in marketing of destinations'. Journal of Travel Research 50 (1), pp. 3-14.

Catanescu, C. \& Tom, G. (2001). 'Types of humor in television and magazine advertising'. Review of Business 22 (1/2), pp. 92-95.

Chandler, D. (2007). Semiotics: The Basics. London: Routledge.

Chathoth, P. K., Ungson, G. R., Harrington, R. J., Chan, E. S., Okumus, F. \& Okumus, F. (2016). 'Co-creation and higher order customer engagement in hospitality and tourism services: a critical review'. International Journal of Contemporary Hospitality Management 28 (2), pp. 222-245.

China Daily. (2015). 'China's social media flurry of gossip, jokes and parodies'. Retrieved on May 22, 2014 from http://usa.chinadaily.com.cn/life/2015-02/10/content_19542143.htm.

Cohen, J. (1960). 'A coefficient of agreement for nominal scales'. Educational and Psychological Measurement 20 (1), pp. 37-46.

Cohen, E. (2011). 'The people of tourism cartoons'. Anatolia 22 (3), pp. 326-349.

Crilly, N., Moultrie, J. \& Clarkson, P. J. (2004). 'Seeing things: consumer response to the visual domain in product design'. Design studies 25 (6), pp. 547-577.

Dann, G. M. (1996). The Language of Tourism: A Sociolinguistic Perspective. Wallingford, UK: CABI.

Decrop, A. (2007). 'The influence of message format on the effectiveness of print advertisements for tourism destinations'. International Journal of Advertising 26 (4), pp. 505-525.

Elo, S. \& Kyngäs, H. (2008). 'The qualitative content analysis process'. Journal of Advanced Nursing 62 (1), pp. 107-115.

Fereday, J. \& Muir-Cochrane, E. (2006). 'Demonstrating rigor using thematic analysis: A hybrid approach of inductive and deductive coding and theme development'. International journal of qualitative methods 5 (1), pp. 80-92.

Filani, I. (2016). “"Laf wan kill me die"(I almost died laughing): An analysis of Akpos jokes and the readers' responses'. European Journal of Humour Research 4 (4), pp. 5-25.

Ford, T. E. \& Ferguson, M. A. (2004). 'Social consequences of disparagement humor: A prejudiced norm theory'. Personality and Social Psychology Review 8 (1), pp. 79-94.

Freese, J. H. (1939). The 'Art' of Rhetoric. Cambridge, MA: Harvard University Press.

Ge, J. (2017). 'Humour in customer engagement on Chinese social media. Doctoral Dissertation Summary'. European Journal of Tourism Research 15, pp. 171-174.

Ge, J. \& Gretzel, U. (2019). 'Social media-based visual strategies in tourism marketing'. International Journal of Semiotics and Visual Rhetoric. (In press).

Ge, J. \& Gretzel, U. (2018). 'Impact of humour on firm-initiated social media conversations'. Information Technology \& Tourism 18 (1-4), pp. 61-83.

Gluscevskij, D. (2017). 'Methodological issues and prospects of semiotics of humour'. Sign Systems Studies 45 (1/2), pp. 137-151.

Gretzel, U. (2015). 'Tourism and humour'. Annals of Tourism Research 57 (March), pp. 290291. 
Gretzel, U. (2017). 'The visual turn in social media marketing'. Tourismos 12 (3), pp. 1-18.

Gretzel, U. \& Yoo, K. H. (2013). 'Premises and promises of social media marketing in tourism', in McCabe, S. (ed.), The Routledge Handbook of Tourism Marketing. London: Routledge, pp. 491-504.

Gretzel, U. \& Fesenmaier, D. R. (2012). 'Customer relations 2.0 - implications for destination marketing (abstract)'. Paper presented at the TTRA Annual International Conference, Virginia Beach, VA., June 17-19.

Govers, R., Go, F. M. \& Kumar, K. (2007). 'Virtual destination image a new measurement approach'. Annals of Tourism Research 34 (4), pp. 977-997.

Highfield, T. \& Leaver, T. (2016). 'Instagrammatics and digital methods: studying visual social media, from selfies and GIFs to memes and emoji'. Communication Research and Practice 2 (1), pp. 47-62.

Holt, D. (2016). 'Branding in the age of social media'. Harvard Business Review 94 (3), pp. 4050.

Hunter, W. C. (2013). 'China's Chairman Mao: A visual analysis of Hunan Province online destination image'. Tourism Management 34 (February), pp. 101-111.

Hunter, W. C. (2015). 'The visual representation of border tourism: Demilitarized zone (DMZ) and Dokdo in South Korea'. International Journal of Tourism Research 17 (2), pp. 151160.

Hunter, W. C. (2016). 'The social construction of tourism online destination image: A comparative semiotic analysis of the visual representation of Seoul'. Tourism Management 54 (June), pp. 221-229.

Hwang, K.-K. (2000). 'Chinese relationalism: Theoretical construction and methodological considerations'. Journal for the Theory of Social Behaviour 30 (2), pp. 155-178.

Jenkins, O. H. (2003). 'Photography and travel brochures: The circle of representation'. Tourism Geographies 5 (3), pp. 305-28.

Kelly, J. P. \& Solomon, P. J. (1975). 'Humor in television advertising'. Journal of Advertising 4 (3), pp. 31-35.

Knight, N. K. (2008). 'Still cool... and american too!': An SFL analysis of deferred bonds in internet messaging humour'. Systemic Functional Linguistics in Use 27, pp. 601-620.

Kolbe, R. H. \& Burnett, M. S. (1991). 'Content-analysis research: An examination of applications with directives for improving research reliability and objectivity'. Journal of Consumer Research 18 (2), pp. 243-250.

Kuipers, G. (2008). 'The sociology of humor', in Raskin, V. (ed.), The Primer of Humor Research, Berlin and New York: Mouton de Gruyter, pp. 361-398.

Kwok, L. \& Yu, B. (2013). 'Spreading social media messages on Facebook an analysis of restaurant business-to-consumer communications'. Cornell Hospitality Quarterly 54 (1), pp. 84-94.

Laineste, L. \& Voolaid, P. (2016). 'Laughing across borders: Intertextuality of internet memes'. European Journal of Humour Research 4 (4), pp. 26-49.

Lanham, R. A. (2006). The Economics of Attention: Style and Substance in the Age of Information. Chicago: University of Chicago Press.

Laroche, M., Vinhal Nepomuceno, M. \& Richard, M.-O. (2014). 'Congruency of humour and cultural values in print ads: Cross-cultural differences among the US, France and China'. International Journal of Advertising 33 (4), pp. 681-705.

Leung, X. Y., Leung, X. Y., Bai, B., Bai, B., Erdem, M. \& Erdem, M. (2017). 'Hotel social media marketing: a study on message strategy and its effectiveness'. Journal of Hospitality and Tourism Technology 8 (2), pp. 239-255. 
Lian, T. \& Yu, C. (2017). 'Representation of online image of tourist destination: a content analysis of Huangshan'. Asia Pacific Journal of Tourism Research 22 (10), pp. 1063-1082.

Lo, I. S. \& McKercher, B. (2015). 'Ideal image in process: Online tourist photography and impression management'. Annals of Tourism Research 52 (May), pp. 104-116.

Lynch, O. H. (2002). 'Humorous communication: Finding a place for humor in communication research'. Communication Theory 12 (4), pp. 423-445.

Marone, V. (2016). 'Looping out loud: A multimodal analysis of humour on Vine'. European Journal of Humour Research 4 (4), pp. 50-66.

Martin, R. A. (2008). 'Humour and health', in Raskin, V. (ed.), The Primer of Humor Research, Berlin and New York: Mouton de Gruyter, pp. 479-522.

Metro-Roland, M. (2009). 'Interpreting meaning: An application of Peircean semiotics to tourism'. Tourism Geographies 11 (2), pp. 270-279.

Meyer, J. C. (2000). 'Humor as a double-edged sword: Four functions of humor in communication'. Communication Theory 10 (3), pp. 310-331.

Moriarty, S. (2005). 'Visual semiotics theory', in Smith, K.L., Moriarty, S., Kenney, K. \& Barbatsis G. (eds.), Handbook of Visual Communication: Theory, Methods, and Media. London: Routledge, pp. 227-224.

Morreall, J. (2008). 'Philosophy and religion', in Raskin, V. (ed.), The Primer of Humor Research, Berlin and New York: Mouton de Gruyter, pp. 211-242.

Pearce, P. L. \& Pabel, A. (2015). Tourism and humour. Bristol: Channel View Publications.

Pabel, A. \& Pearce, P. L. (2016a). 'Exploring variations in humour use across tourism settings'. Paper presented at CAUTHE 2016: The Changing Landscape of Tourism and Hospitality: The Impact of Emerging Markets and Emerging Destinations. Sydney, Australia, February 8-11.

Pabel, A. \& Pearce, P. L. (2016b). 'Tourists' responses to humour'. Annals of Tourism Research 57 (March), pp. 190-205.

Pearce, P. L. (2009). 'Now that is Funny'. Annals of Tourism Research 36 (4), pp. 627-644.

Peirce, C. S. (1991). Peirce on Signs: Writings on Semiotic. Chapel Hill and London: The University of North Carolina Press.

Pennington, J. W. \& Thomsen, R. C. (2010). 'A semiotic model of destination representations applied to cultural and heritage tourism marketing'. Scandinavian Journal of Hospitality and Tourism 10 (1), pp. 33-53.

Radcliffe-Brown, A. R. (1940). 'On joking relationships.' Africa 13 (3), pp. 195-210.

Raskin, V. (2008). The Primer of Humor Research. Berlin and New York: Mouton de Gruyter.

Rieck, D. (1997). 'Waiting for Guffaw: A serious look at humor and why you should avoid it'. Direct Marketing 59 (12), pp. 36-37.

Ritchie, G. (2001). 'Current directions in computational humour'. Artificial Intelligence Review 16 (2), pp. 119-135.

Rose, G. (2016). Visual Methodologies: An Introduction to Researching with Visual Materials. London: SAGE.

Ruch, W. (2008). 'Psychology of humor', in Raskin, V. (ed.), The Primer of Humor Research, Berlin and New York: Mouton de Gruyter, pp. 17-100.

Shriner, K. (2017). 'Help travellers choose your destination with eye-popping visual content'. November 24. Destination Think!. Retrieved October, 2018 from: https://destinationthink.com/travellers-choose-destination-visual-content/.

Shifman, L. (2007). 'Humor in the age of digital reproduction: Continuity and change in Internet-based comic texts'. International Journal of Communication 1, pp. 187-209.

Shifman, L. (2012). 'An anatomy of a YouTube meme'. New Media \& Society 14 (2), pp. 187203. 
Shifman, L. (2013). Memes in Digital Culture. Cambridge, MA: MIT Press.

Shifman, L., Coleman, S. \& Ward, S. (2007). 'Only joking? Online humour in the 2005 UK general election'. Information, Community and Society 10 (4), pp. 465-487.

Speck, P. S. (1990). 'The humorous message taxonomy: A framework for the study of humorous Ads'. Current Issues \& Research in Advertising 13 (1), pp. 1-44.

Stepchenkova, S. \& Zhan, F. (2013). 'Visual destination images of Peru: Comparative content analysis of DMO and user-generated photography'. Tourism Management 36 (June), pp. 590-601.

Thomson, D. (2010). 'The social meaning and function of humour in physiotherapy practice: An ethnography.' Physiotherapy Theory and Practice 26 (1), pp. 1-11.

Thomsen, R. C. \& Vester, S. P. (2016). 'Towards a semiotics-based typology of authenticities in heritage tourism: Authenticities at Nottingham Castle, UK, and Nuuk Colonial Harbour, Greenland'. Scandinavian Journal of Hospitality and Tourism 16 (3), pp. 254-273.

Tresidder, R. (2014). 'The semiotics of tourism marketing', in MacCabe, S. (ed.), The Routledge Handbook of Tourism Marketing. London: Routledge, pp. 116-128.

Tsakona, V. (2009). 'Language and image interaction in cartoons: Towards a multimodal theory of humour'. Journal of Pragmatics 41 (6), pp. 1171-1188.

Wellman, B., Quan-Haase, A., Boase, J., Chen, W., Hampton, K., Diaz, I. \& Miyata, K. (2003). 'The social affordances of the Internet for networked individualism'. Journal of ComputerMediated Communication 8 (3), pp. 1031-1049.

Weitz, E. (2016). 'Humour and social media'. European Journal of Humour Research 4 (4), pp. 1-4.

Zhang, X. \& Sheng, J. (2017). 'A Peircean semiotic interpretation of a social sign'. Annals of Tourism Research 64 (May), pp. 163-173. 